\title{
ANALISIS TANAMAN OBAT YANG MENJADI PRIORITAS UNTUK DIKEMBANGKAN DI JAWA TENGAH
}

\author{
Nurul Husniyati Listyana \\ Balai Besar Penelitian dan Pengembangan Tanaman Obat dan Obat Tradisional Tawangmangu \\ E-mail: nurul.haydar@gmail.com
}

\begin{abstract}
The aim of this study is to analyze the index Location Quotient of ginger, kencur, turmeric and galangal; to analyze the value of the growth component of ginger, kencur, turmeric and galangal; to analyze the types of medicinal plants is a priority for development in Central Java. This research uses descriptive method with secondary data sources coming from the Badan Pusat Statistik. In this study analyzed the competitiveness of the four regions, namely medicinal plant ginger, kencur, turmeric and galangal. The results showed Ginger has $L Q<1$ while kencur, turmeric and galangal has $L Q>1$. Ginger has a value component of positive growth while kencur, turmeric and galangal has a negative value. Ginger has a value of share growth component negative territory while kencur, turmeric and galangal has a positive value. Kencur, turmeric and galangal is a commodity that is becoming a priority for development in Central Java Province.
\end{abstract}

Keywords: ginger, kencur, turmeric, galangal, priority

\begin{abstract}
Abstrak : Tujuan dari penelitian ini yaitu untuk menganalisis indeks Location Quotient jahe, kencur, kunyit dan lengkuas; untuk menganalisis nilai komponen pertumbuhan dari jahe, kencur, kunyit dan lengkuas; untuk menganalisis jenis tanaman obat yang menjadi prioritas untuk dikembangkan di Jawa Tengah. Penelitian ini menggunakan metode deskriptif dengan sumber data sekunder yang berasal dari Badan Pusat Statistik. Dalam penelitian ini dianalisis daya saing wilayah empat tanaman obat yaitu jahe, kencur, kunyit dan lengkuas. Hasil penelitian menunjukkan Jahe mempunyai indeks LQ $<1$ sedangkan kencur, kunyit dan lengkuas mempunyai indeks LQ > 1. Jahe mempunyai nilai komponen pertumbuhan positif sedangkan kencur, kunyit dan lengkuas mempunyai nilai negatif. Jahe mempunyai nilai komponen pertumbuhan pangsa wilayah negatif sedangkan kencur, kunyit dan lengkuas mempunyai nilai yang positif. Kencur, kunyit dan lengkuas merupakan komoditas yang menjadi prioritas untuk dikembangkan di Propinsi Jawa Tengah.
\end{abstract}

Kata Kunci : jahe, kencur, kunyit, lengkuas, prioritas

\section{PENDAHULUAN}

Tanaman obat adalah jenis-jenis tanaman yang memiliki fungsi dan berkhasiat sebagai obat dan dipergunakan untuk penyembuhan ataupun mencegah berbagai penyakit. Seiring dengan meningkatnya kesadaran masyarakat untuk menggunakan bahan-bahan alami dalam kehidupan sehari-hari, kebutuhan tanaman obat sebagai bahan baku obat tradisional juga semakin meningkat. Tanaman obat tidak hanya diolah secara tradisional, namun dewasa ini tanaman obat sudah diolah secara modern di industri-industri jamu. Penggunaan obat tradisional saat ini tidak lagi terbatas pada masyarakat pedesaan saja namun sudah merambah pada masyarakat yang kehidupannya lebih modern.

Penggunaan obat tradisional seringkali masih menjadi pertentangan di pelayananpelayanan kesehatan yang ada di sekitar kita. Dengan adanya Permenkes nomor 003/MENKES/PER/I/2010 tentang Saintifikasi Jamu, saat ini penggunaan obat tradisional yang 
menggunakan bahan baku tanaman obat bisa berjalan beriringan dengan penggunaan obatobatan kimia.

Indonesia memiliki ketergantungan yang besar terhadap bahan baku dan obat konvensional impor senilai 160 juta USD/tahun, sehingga perlu disubstitusi oleh produk dalam negeri. Trend global "back to nature" menunjukkan pertumbuhan pesat, termasuk di Indonesia, sehingga "jamu" sebagai produk tanaman obat (TO) khas Indonesia memiliki arti strategis di bidang kesehatan, juga dalam "Program Revitalisasi Pertanian" yang bertujuan untuk meningkatkan kesejahteraan rakyat (Badan Litbang Pertanian, 2007).

Masalah yang dihadapi dalam pemanfaatan TO untuk pelayanan kesehatan formal, sebagai sumber devisa dan PDB di Indonesia adalah: (1) belum ada dukungan politik yang kuat dari pemerintah untuk menjadikan TO obat resmi dan salah satu sumber kesejahteraan rakyat; (2) belum ada program menyeluruh dan terpadu dari hulu hingga hilir untuk pengembangan dan pemanfaatan TO nasional ; (3) kurangnya koordinasi dan sinkronisasi program antar instansi pemerintah, swasta dan litbang, sehingga program yang ada menjadi kurang terarah, kurang efektif dan kurang efisien; (4) Undang-undang kesehatan yang ada belum kondusif bagi pemanfaatan TO dalam pelayanan kesehatan formal (Badan Litbang Pertanian, 2005).

Jahe, kencur, kunyit dan lengkuas merupakan jenis tanaman obat yang banyak dihasilkan di wilayah Indonesia. Kebutuhan industri obat tradisional akan jahe, kencur, kunyit dan lengkuas pada tahun 2007 masingmasing sebesar 5000 ton/tahun; 2000 ton/tahun; 3000 ton/tahun dan 180 ton/tahun (Maximillian, 2007). Hampir seluruh propinsi di Indonesia menghasilkan empat tanaman obat tersebut. Namun demikian, daya saing yang dimilki masing-masing propinsi berbeda-beda. Untuk itulah akan dilakukan penelitian mengenai analisis daya saing wilayah terhadap empat komoditas tanaman tersebut di propinsi Jawa Tengah. Dengan demikian pembangunan dapat diarahkan pada pembangunan dan pembinaan keunggulan tersebut dimasa yang akan datang (Suryana, 2000). Dengan adanya prioritas pembangunan berdasarkan potensi yang dimiliki masing-masing daerah, maka akan terjadi proses pertumbuhan ekonomi di daerah tersebut (Ratnasari, 2014). Tujuan dari penelitian ini yaitu menganalisis indeks Location Quotient jahe, kencur, kunyit dan lengkuas; menganalisis nilai komponen pertumbuhan jahe, kencur, kunyit dan lengkuas serta menganalisis jenis tanaman obat yang menjadi prioritas untuk dikembangkan di Jawa Tengah

\section{METODE PENELITIAN}

Penelitian ini dilaksanakan di Propinsi Jawa Tengah. Metode dasar yang digunakan dalam penelitian adalah metode deskriptif. Propinsi Jawa Tengah dipilih karena berdasarkan data dari Badan Pusat Statistik dan Kementerian Pertanian Jawa Tengah merupakan penghasil terbesar untuk komoditas jahe, kencur, kunyit dan lengkuas. Data yang diperlukan berupa data sekunder yang diperoleh dari Badan Pusat Statistik Jawa Tengah. Data yang dianalisis merupakan data produksi empat jenis tanaman obat selama kurun waktu 2010-2014.

\section{Tempat dan Waktu Penelitian}

Penelitian dilaksanakan di Propinsi Jawa Tengah pada tahun 2015

\section{Metode Analisis Data}

Untuk menganalisis apakah suatu sektor/jenis komoditas merupakan sektor basis atau non basis digunakan analisis Location Quotient. Sektor basis yaitu sektor yang mampu mencukupi kebutuhan domestik sedangkan sektor non basis yaitu sektor yang belum mampu mencukupi kebutuhan domestik wilayahnya. Dengan analisis Location Quotient dapat diketahui komoditas apa yang bisa mencukupi kebutuhan domestik dan mempunyai kemungkinan untuk dikembangkan sebagai komoditas prioritas. Analisis Location Quotient dirumuskan sebagai berikut :

$$
L Q=\frac{S i / N i}{S / N}=\frac{S i / S}{N i / N}
$$

Dimana :

$\mathrm{Si}=$ Jumlah produksi tanaman obat komoditas i di daerah yang diselidiki

$\mathrm{S}=$ Jumlah produksi seluruh tanaman obat di daerah yang diselidiki 
$\mathrm{Ni}=$ Jumlah produksi tanaman obat komoditas i di daerah acuan yang lebih luas, di mana daerah yang di selidiki menjadi bagiannya

$\mathrm{N}=$ Jumlah seluruh produksi tanaman obat di daerah acuan yang lebih luas

Dari perhitungan Location Quotient (LQ), kriteria umum yang dihasilkan adalah :

a) Jika LQ > 1, komoditas tanaman obat menjadi basis, yaitu tingkat spesialisasinya lebih tinggi daripada tingkat wilayah acuan (mampu mencukupi kebutuhan domestik wilayahnya serta mampu mengekspor keluar wilayah)

b) Jika LQ < 1, disebut non-basis, yaitu tingkat spesialisasinya lebih rendah daripada tingkat wilayah acuan (belum mampu mencukupi kebutuhan domestik wilayahnya serta masih mengimpor dari wilayah lain)

c) Jika LQ $=1$, maka tingkat spesialisasi daerah sama dengan tingkat wilayah acuan (mampu mencukupi kebutuhan domestik wilayahnya namun belum mampu mengekspor keluar wilayah)

(Bendavid, 1972 dalam Kuncoro, 2004)

Untuk menganalisis nilai komponen pertumbuhan masing-masing sektor digunakan analisis Shift Share. Analisis Shift Share juga dapat digunakan untuk mengetahui kinerja perekonomian daerah, pergeseran struktur, posisi relatif sektor-sektor ekonomi dan identifikasi sektor unggulan daerah dalam kaitannya dengan perekonomian wilayah acuan dalam dua atau lebih kurun waktu. Shift Share Analysis berguna untuk melihat perkembangan wilayah terhadap wilayah yang lebih luas misalnya perkembangan kabupaten terhadap propinsi atau propinsi terhadap nasional, dengan Shift Share dapat di ketahui perkembangan sektor-sektor di banding sektor lainnya serta dapat membandingkan laju perekonomian di suatu wilayah (Mangilaleng et al, 2015). Dalam penelitian ini analisis Shift Share digunakan untuk melihat bagaimana pola pertumbuhan komoditas tanaman obat di Jawa Tengah serta untuk melihat daya saing komoditas tanaman obat di Jawa Tengah jika dibandingkan dengan komoditas tanaman obat dari daerah lain dalam skala yang lebih luas (tingkat nasional). Analisis Shift Share dapat dirumuskan sebagai berikut :

$$
\Delta K i j=P N i j+P P i j+P P W i j
$$

Atau secara rinci dapat dinyatakan sebagai berikut:

$\left(\mathrm{K}^{\prime} \mathrm{ij}-\mathrm{Kij}\right)=\Delta \mathrm{Kij}=\mathrm{Kij}(\mathrm{Ra}-1)+\mathrm{Kij}(\mathrm{Ri}-$ $\mathrm{Ra})+\mathrm{Kij}(\mathrm{ri}-\mathrm{Ri})$

$$
\begin{array}{ll}
\mathrm{ri} & =\mathrm{K}^{\prime} \mathrm{ij} / \mathrm{Kij} \\
\mathrm{Ri} & =\mathrm{K}^{\prime} \mathrm{i} / \mathrm{Ki} \\
\mathrm{Ra} & =\mathrm{K}^{\prime} . . / \mathrm{K} . . \\
\mathrm{PNij} & =(\mathrm{Ra}-1) \quad \times \mathrm{Kij} \\
\text { PPij } & =(\mathrm{Ri}-\mathrm{Ra}) \times \mathrm{Kij} \\
\text { PPWij } & =(\mathrm{ri}-\mathrm{Ri}) \quad \times \mathrm{Kij}
\end{array}
$$

Keterangan:

$\Delta \mathrm{Kij}=$ Perubahan PDRB di Propinsi Jawa Tengah

Kij = PDRB komoditas tanaman obat di Propinsi Jawa Tengah pada tahun analisis

$\mathrm{K}^{\prime} \mathrm{ij}=$ PDRB komoditas tanaman obat $\mathrm{di}$ Propinsi Jawa Tengah pada akhir tahun analisis

$\mathrm{Ki}=$ PDRB komoditas tanaman obat Indonesia pada tahun dasar analisis

$\mathrm{K}^{\prime} \mathrm{i}=$ PDRB komoditas tanaman obat Provinsi Jawa Tengah pada tahun akhir analisis

K.. = PDRB komoditas tanaman obat Indonesia pada tahun dasar analisis

$\mathrm{K}^{\prime} . . \quad=$ PDRB komoditas tanaman obat Indonesia pada tahun akhir analisis

Ra-1 = Persentase perubahan PDRB komoditas tanaman obat Propinsi Jawa Tengah yang disebabkan komponen pertumbuhan nasional

$\mathrm{Ri}-\mathrm{Ra}=$ Persentase perubahan PDRB komoditas tanaman obat Propinsi Jawa Tengah yang disebabkan komponen pertumbuhan proporsional

ri-Ri $=$ Persentase perubahan PDRB komoditas tanaman obat Propinsi Jawa Tengah yang disebabkan komponen pertumbuhan pangsa wilayah. 
Nurul Husniyati L. : Analisis Tanaman Obat Yang Menjadi Prioritas ...

Tabel 1. Tabel gabungan nilai Location Quotient dan Shift Share untuk penentuan tanaman obat prioritas

\begin{tabular}{llll}
\hline Prioritas & LQ & PP & PPW \\
\hline PrioritasPertama & $>1$ & Positif & Positif \\
PrioritasKedua & $>1$ & Negatif & Positif \\
& $>1$ & Positif & Negatif \\
PrioritasAlternatif & $>1$ & Negatif & Negatif \\
\hline
\end{tabular}

(Budiharsono, 2001).

Dengan kriteria:

1) Apabila PPij positif, maka komoditas tanaman obat di Propinsi Jawa Tengah pertumbuhannya cepat.

2) Apabila PPij negatif, maka komoditas tanaman obat di Propinsi Jawa Tengah pertumbuhannya lambat.

3) Apabila PPWij positif, maka komoditas tanaman obat di Jawa Tengah mempunyai daya saing yang baik jika dibandingkan dengan komoditas tanaman obat yang sama di wilayah lainnya.

4) Apabila PPWij < 0, maka komoditas tanaman obat di Propinsi Jawa Tengah tidak dapat bersaing dengan baik jika dibandingkan dengan komoditas tanaman obat yang sama di wilayah lainnya.

Untuk menganalisis jenis tanaman obat yang menjadi prioritas untuk dikembangkan di Jawa Tengah digunakan hasil analisis gabungan dari Location Quotient dan Shift Share yang dirangkum dalam tabel 1.

Chadiq, dkk (2010) menggunakan gabungan analisis LQ dan Shift Share untuk mengidentifikasi sektor-sektor potensial di wilayah Jawa Tengah. Hasil dari penelitian tersebut menunjukkan bahwa hampir semua kabupaten di Jawa Tengah memiliki nilai komponen pertumbuhan proporsional positif kecuali Kabupaten Kudus, Kabupaten Semarang, Kota Salatiga dan Kota Semarang. Sedangkan Oktavia, dkk (2015) menggunakan gabungan analisis LQ dan Shift Share untuk mengidentifiksi sektor unggulan di Propinsi Sumatera Selatan. Hasil penelitian menunjukkan bahwa sektor pertanian merupakan sektor unggulan di Sumatera Selatan namun pertumbuhan masih lebih lambat dibanding dengan sektor lainnya. Berdasarkan Kesuma dan Utama (2015) gabungan analisis Location Quotient dan Shift Share digunakan untuk menganalisis sektorsektor perekonomian yang menjadi unggulan di Kabupaten Klungkung. Hasil penelitian menunjukkan bahwa sektor pertanian, sektor pertambangan dan penggalian, sektor bangunan dan sektor jasa merupakan sektor-sektor yang menjadi unggulan di Kabupaten Klungkung. Lolowang et al (2014) juga menggunakan analisis LQ dan Shift Share untuk mengetahui sektor yang menjadi basis perekonomian di Kabupaten Minahasa serta untuk mengetahui daya saing wilayah sektor-sektor perekonomian. Hasil penelitian menunjukkan bahwa sektor pertanian, sektor pertambangan dan penggalian, sektor listrik,gas, dan air bersih merupakan basis perekonomian di Kabupaten Minahasa. Dari seluruh sektor perekonomian yang ada, tidak ada satupun yang mempunyai daya saing wilayah.

\section{HASIL DAN PEMBAHASAN}

Jawa Tengah merupakan salah satu propinsi di Indonesia yang erat kaitannya dengan jamu. Tradisi turun temurun dalam mengkonsumsi jamu sudah diwariskan sejak jaman dahulu. Hal ini seperti tercantum dalam tulisan-tulisan kuno seperti lontar usada, kitab Gatotkaca Sraya, kitab kakawin Bhomaukaya, serat Centhini, serat Kwaruh, serat Primbon Jampi Jawi dan lain-lain. Tradisi yang turun temurun ini membuat masyarakat di Jawa Tengah menanam berbagai jenis tanaman obat terutama emponempon. Selain menanam untuk kebutuhan sendiri, banyak masyarakat yang menanam tanaman obat untuk dijual untuk memenuhi kebutuhan industri obat tradisional. Jenis empon-empon yang banyak ditanam oleh masyarakat di Jawa Tengah yaitu jahe, kunyit, kencur dan lengkuas. 
Tabel 2. Tabel jumlah produksi jahe, kunyit, kencur dan lengkuas di Jawa Tengah tahun 2010-2014

\begin{tabular}{|l|r|r|r|c|c|}
\hline & \multicolumn{1}{|c|}{2010} & \multicolumn{1}{c|}{2011} & \multicolumn{1}{c|}{2012} & 2013 & 2014 \\
\hline Jahe & 30.850 .553 & 20.639 .107 & 26.174 .641 & 33.760 .329 & 42.363 .430 \\
\hline Kencur & 6.209 .325 & 8.397 .116 & 11.683 .983 & 13.625 .379 & 10.100 .291 \\
\hline Kunyit & 28.139 .446 & 18.928 .493 & 20.362 .434 & 38.158 .928 & 38.933 .038 \\
\hline Lengkuas & 15.880 .568 & 10.946 .153 & 14.231 .059 & 19.580 .700 & 18.305 .869 \\
\hline
\end{tabular}

Sumber : Badan Pusat Statistik, 2015

Tabel 3. Daftar produksi jahe,kencur, kunyit dan lengkuas per Kabupaten tahun 2013

\begin{tabular}{|c|c|c|c|c|c|c|c|c|c|}
\hline \multirow{2}{*}{ No } & \multirow{2}{*}{ Kabupaten } & \multicolumn{2}{|c|}{ Jahe } & \multicolumn{2}{|c|}{ Kencur } & \multicolumn{2}{|c|}{ Kunyit } & \multicolumn{2}{|c|}{ Lengkuas } \\
\hline & & Luaspanen & Produksi & Luaspanen & Produksi & LuasPanen & Produksi & LuasPanen & Produksi \\
\hline 1 & KabupatenCilacap & 273,186 & 314,425 & 115,237 & 178,043 & 137,480 & 280,368 & 83,339 & 194,731 \\
\hline 2 & KabupatenBanyumas & 173,754 & 215,309 & 152,377 & 172,636 & 297,646 & 613,161 & 175,201 & 359,846 \\
\hline 3 & KabupatenPurbalingga & 32,130 & 38,770 & 16,649 & 15,079 & 19,212 & 28,907 & 20,902 & 77,105 \\
\hline 4 & KabupatenBanjarnegara & 448,980 & 470,960 & 120,074 & 96,926 & 252,311 & 333,561 & 156,634 & 344,609 \\
\hline 5 & KabupatenKebumen & 79,398 & 109,977 & 42,908 & 41,754 & 104,091 & 107,457 & 36,567 & 71,704 \\
\hline 6 & KabupatenPurworejo & 398,532 & 899,458 & 151,903 & 207,974 & 113,429 & 205,201 & 103,767 & 232,130 \\
\hline 7 & KabupatenWonosobo & 404,112 & 678,571 & 26,415 & 31,489 & 10,509 & 12,215 & 5,400 & 11,783 \\
\hline 8 & KabupatenMagelang & 602,500 & $1,621,337$ & 171,560 & 242,720 & 370,000 & $1,124,000$ & 56,400 & 163,110 \\
\hline 9 & KabupatenBoyolali & $1,003,880$ & $1,246,675$ & $2,074,430$ & $3,968,814$ & 29,435 & 39,250 & 15,670 & 28,456 \\
\hline 10 & KabupatenKlaten & 10,710 & 3,268 & 130 & 130 & 1,836 & 2,760 & 366 & 849 \\
\hline 11 & KabupatenSukoharjo & 33,743 & 120,647 & 12,730 & 28,597 & 407,115 & $1,245,608$ & 41,381 & 133,356 \\
\hline 12 & KabupatenWonogiri & $3,289,459$ & $14,037,522$ & $1,296,138$ & $3,864,198$ & $5,114,565$ & $22,259,752$ & $1,764,468$ & $9,722,190$ \\
\hline 13 & KabupatenKaranganyar & $1,788,782$ & $1,791,458$ & 96,838 & 88,513 & 638,559 & 634,385 & 353,638 & 697,495 \\
\hline 14 & KabupatenSragen & 9,348 & 11,941 & 96,167 & 303,684 & 12,456 & 24,944 & 12,569 & 72,171 \\
\hline 15 & KabupatenGrobogan & 17,610 & 42,354 & 12,822 & 22,406 & 22,222 & 56,460 & 22,217 & 66,380 \\
\hline 16 & KabupatenBlora & 148,022 & 306,281 & 35,404 & 90,764 & 141,507 & 398,396 & 223,949 & $1,010,400$ \\
\hline 17 & KabupatenRembang & $1,692,827$ & $4,751,575$ & 542,267 & $1,083,516$ & $2,328,276$ & $5,637,224$ & 522,709 & $1,623,124$ \\
\hline 18 & KabupatenPati & 40,664 & 33,721 & 58,215 & 41,574 & 35,519 & 25,332 & 8,060 & 41,525 \\
\hline 19 & Kabupaten Kudus & 534,000 & 567,800 & $1,680,518$ & $2,759,672$ & 133,040 & 142,794 & 485,673 & $1,416,175$ \\
\hline 20 & KabupatenJepara & 12,531 & 26,644 & 98,162 & 225,645 & 8,048 & 14,669 & 390,491 & $1,177,868$ \\
\hline 21 & KabupatenDemak & 46,434 & 79,954 & 9,571 & 13,065 & 146,889 & 253,558 & 23,743 & 64,425 \\
\hline 22 & Kabupaten Semarang & $2,414,965$ & $4,390,475$ & 39,230 & 22,136 & $1,628,225$ & $2,244,665$ & 215,977 & 648,475 \\
\hline 23 & KabupatenTemanggung & $1,139,200$ & 805,117 & 600 & 1,275 & 136,120 & 278,663 & 222,000 & 661,487 \\
\hline 24 & Kabupaten Kendal & 15,474 & 20,562 & 11,160 & 8,841 & 287,675 & 566,634 & 12,550 & 16,463 \\
\hline 25 & KabupatenBatang & 60,670 & 101,490 & 29,900 & 48,108 & 41,200 & 67,070 & 14,866 & 57,333 \\
\hline 26 & KabupatenPekalongan & 172,218 & 147,500 & 21,051 & 21,022 & 31,430 & 62,910 & 100,753 & 352,957 \\
\hline 27 & KabupatenPemalang & 37,007 & 83,411 & 11,918 & 18,392 & 69,153 & 168,555 & 40,859 & 150,470 \\
\hline 28 & KabupatenTegal & 166,252 & 221,324 & 5,335 & 5,540 & 29,456 & 81,045 & 26,471 & 81,086 \\
\hline 29 & KabupatenBrebes & 113,996 & 248,303 & 18,785 & 22,866 & 107,677 & 268,384 & 30,713 & 95,327 \\
\hline 30 & Kota Magelang & - & - & - & - & - & - & - & - \\
\hline 31 & Kota Surakarta & - & - & - & - & - & - & - & - \\
\hline 32 & Kota Salatiga & 305,000 & 365,500 & - & - & 68,000 & 53,000 & - & - \\
\hline 33 & Kota Semarang & 10,000 & 8,000 & - & - & 608,000 & 928,000 & 5 & 7,670 \\
\hline 34 & Kota Pekalongan & - & - & - & - & - & - & - & - \\
\hline 35 & Kota Tegal & - & - & - & - & - & - & - & - \\
\hline
\end{tabular}

Sumber : Badan Pusat Statistik, 2015

Dari keempat jenis empon-empon tersebut, jahe paling banyak hasil produksinya di bandingkan empon-empon yang lain kemudian di susul oleh kunyit. Selain dikonsumsi sendiri di tingkat rumah tangga, jahe dan kunyit merupakan jenis empon-empon yang banyak dibutuhkan oleh industri obat tradisional. Daerah yang merupakan penghasil jahe terbesar di Jawa Tengah yaitu Kabupaten Wonogiri, Kabupaten Rembang, Kabupaten Semarang, 
Kabupaten Karanganyar dan Kabupaten Boyolali.

Daerah penghasil kencur terbesar di Jawa Tengah yaitu Kabupaten Boyolali, Kabupaten Wonogiri, Kabupaten Kudus dan Kabupaten Rembang. Daerah penghasil kunyit terbesar yaitu Kabupaten Wonogiri, Kabupaten Rembang, Kabupaten Semarang, Kabupaten Sukoharjo dan Kabupaten Magelang. Sedangkan daerah penghasil lengkuas terbesar yaitu Kabupaten Wonogiri, Kabupaten Rembang, Kabupaten Kudus, Kabupaten Jepara dan Kabupaten Blora. Jika dilihat dari segi produktivitas, daerah yang mempunyai produktivitas tertinggi yaitu Kabupaten Wonogiri dengan nilai produktivitas sebesar $4,267 \mathrm{~kg} / \mathrm{m} 2$ dan produktivitas terendah Kabupaten Klaten dengan nilai produktivitas sebesar $0,305 \mathrm{~kg} / \mathrm{m} 2$.

Dari hasil perhitungan nilai LQ di atas dapat dilihat bahwa dari keempat komoditas tanaman obat yang diteliti, hanya jahe yang memiliki nilai $L Q \leq 1$. Hal ini berarti produksi jahe di Jawa Tengah belum mampu mencukupi kebutuhan intern di Jawa Tengah sendiri. Sedangkan untuk kencur, kunyit dan lengkuas mempunyai nilai $L Q \geq 1$ yang artinya selain mampu digunakan untuk mencukupi kebutuhan daerahnya sendiri, produksi ketiga komoditas tersebut juga dapat diekspor ke luar wilayah Jawa Tengah.

Kenyataan di lapang menunjukkan bahwa agribisnis tanaman obat tidak berkembang dengan baik dan merata, karena petani dan pelaku usaha kurang memahami kebutuhan pasar domestik dan ekspor yang menginginkan produk siap pakai yang telah diolah. Kurangnya pemahaman tersebut karena menjual tanaman obat memang tak semudah menjual tanaman hortikultura lainnya, seperti sayur-sayuran atau buah-buahan. Disamping itu, keengganan petani untuk mengusahakan tanaman obat karena permintaannya relative belum semassal komoditas sayur-sayuran atau pun buah-buahan dan diantara ratusan jenis yang diperlukan industri obat tradisional hanya sedikit tanaman yang biasa dibudidayakan petani. Sebagai dampak dari kondisi diatas adalah belum/tidak terpenuhinya jumlah pasokan yang diminta oleh industri obat tradisional akan beberapa komoditas tanaman obat yang diperlukan, baik yang tumbuh liar maupun tanaman yang telah dibudidayakan. Bahkan sangat ironis sekali dengan adanya pernyataan dari APETOI bahwa stok tanaman obat Indonesia hanya cukup memenuhi permintaan untuk enam bulan saja. Hal ini menunjukkan bahwa eksistensi simplisia tanaman obat benar-benar sangat terbatas (Maximillian, 2007).

Untuk menganalisis nilai komponen pertumbuhan dalam penelitian in digunakan Shift Share Analysis. Mangilaleng et al, 2015 menggunakan analisis Shift Share untuk melihat perkembangan wilayah terhadap wilayah yang lebih luas misalnya perkembangan kabupaten terhadap propinsi atau propinsi terhadap nasional. Dengan Shift Share dapat di ketahui perkembangan sektorsektor di banding sektor lainnya serta dapat membandingkan laju perekonomian di suatu wilayah. Hasil perhitungan Shift Share Analysis dapat dilihat pada tabel 5 .

Tabel 4. Perhitungan nilai LQ komoditas jahe, kunyit, kencur dan lengkuas tahun 2010-2014

\begin{tabular}{|l|r|r|r|r|r|r|}
\hline & \multicolumn{1}{|c|}{2010} & \multicolumn{1}{c|}{2011} & \multicolumn{1}{c|}{2012} & \multicolumn{1}{c|}{2013} & \multicolumn{1}{l|}{2014} & Rata-rata \\
\hline Jahe & 1,07 & 1,00 & 0,98 & 0,11 & 0,69 & 0,77 \\
\hline Kencur & 0,78 & 1,71 & 1,18 & 1,13 & 0,78 & 1,20 \\
\hline Kunyit & 0,98 & 1,03 & 0,90 & 1,64 & 1,52 & 1,21 \\
\hline Lengkuas & 1,00 & 0,87 & 1,05 & 1,45 & 1,29 & 1,13 \\
\hline
\end{tabular}

Sumber : analisis data sekunder

Tabel 5. Perhitungan Shift Share Analysis

\begin{tabular}{|l|r|r|r|}
\hline Komoditas & PN & PP & \multicolumn{1}{c|}{ PPW } \\
\hline Jahe & 64419624,27 & 102411951,7 & $-123134793,7$ \\
\hline Kencur & 17722039,75 & $-10569927,75$ & 11420107,12 \\
\hline Kunyit & 64204805,11 & $-59658673,11$ & 36640381,99 \\
\hline Lengkuas & 35256078,87 & $-32183350,87$ & 5932001,504 \\
\hline
\end{tabular}

Sumber : analisis data sekunder 
Tabel 6. Penentuan tanaman obat prioritas

\begin{tabular}{|l|l|l|l|l|}
\hline & LQ & PP & PPW & PRIORITAS \\
\hline Jahe & $<1$ & + & - & Non prioritas \\
\hline Kencur & $\geq 1$ & - & + & II \\
\hline Kunyit & $\geq 1$ & - & + & II \\
\hline Lengkuas & $\geq 1$ & - & + & II \\
\hline
\end{tabular}

Sumber : analisis data sekunder

Dari tabel tersebut di atas dapat dilihat bahwa dari keempat komoditas tanaman obat hanya jahe yang mempunyai nilai PP positif. Hal ini berarti jahe memiliki pertumbuhan yang cepat dalam perkembangannya. Sedangkan jika dilihat dari nilai PPW jahe justru mempunyai nilai negatif.Hal ini menunjukkan bahwa jahe yang berasal dari Jawa Tengah tidak memiliki daya saing dibandingkan jahe dari daerah lain. Sedangkan ketiga komoditas lain mempunyai pertumbuhan yang lambat namun mempunyai daya saing dibandingkan komoditas dari daerah lain.

Tanaman obat prioritas ditentukan dengan menggunakan analisis gabungan LQ dan Shift Share. Analisis ini menggabungkan hasil dari analisis LQ dan Shift Share yang telah dilakukan sebelumnya. Dalam penentuan tanaman prioritas digunakan nilai LQ, PP dan PPW. Hasil analisis gabungan dalam penentuan tanaman obat prioritas dapat dilihat pada tabel 6.

Dari tabel tersebut di atas dapat dilihat bahwa dari keempat komoditas tanaman obat tersebut tidak ada yang masuk prioritas utama untuk dikembangkan. Tanaman jahe memiliki laju pertumbuhan yang bagus, namun hasil panen belum mencukupi kebutuhan. Selain itu tanaman jahe di Jawa Tengah tidak memiliki daya saing dibandingkan tanaman jahe dari propinsi lain. Kencur, kunyit dan lengkuas menjadi prioritas kedua untuk dikembangkan. Ketiga tanaman ini mempunyai tingkat produksi yang tinggi sehingga selain mampu mencukupi kebutuhan domestik juga mampu mengekspor ke Propinsi lain. Selain produksi yang tinggi ketiga tanaman tersebut juga mempunyai daya saing wilayah yang bagus, sehingga ketiga komoditas tersebut akan mampu bersaing dengan komoditas dari propinsi lain. Meskipun produksi tinggi dan daya saing bagus namun ketiga komoditas tersebut mempunyai laju pertumbuhan yang lamban. Hal ini berarti meskipun memiliki prospek yang bagus namun masyarakat masih belum banyak yang mengembangkannya.

Menurut Lestari (2007) keunggulan yang dapat menyebabkan daya saing tinggi antara lain, faktor sumber daya, faktor industri terkait dan pendukung dan faktor kesempatan. Tetapi komponen yang lain seperti faktor permintaan, faktor persaingan, struktur, dan strategi industri, dan faktor pemerintah menyebabkan daya saing menjadi kurang. Keterkaitan antar faktor tidak terjalin secara sempurna sehingga menyebabkan faktor keunggulan tersebut tidak dapat dimanfaatkan untuk mendukungfaktor daya saing yang lain yang lemah. Hal ini mengakibatkan pertumbuhan menjadi lambat.

\section{KESIMPULAN DAN SARAN}

\section{Kesimpulan}

Berdasarkan hasil penelitian tersebut di atas dapat diambil kesimpulan sebagai berikut:

1. Jahe mempunyai indeks LQ $<1$ sedangkan kencur, kunyit dan lengkuas mempunyai indeks LQ > 1.

2. Jahe mempunyi nilai komponen pertumbuhan positif sedangkan kencur, kunyit dan lengkuas mempunyai nilai negatif. Jahe mempunyai nilai komponen pertumbuhan pangsa wilayah negatif sedangkan kencur, kunyit dan lengkuas mempunyai nilai yang positif.

3. Kencur, kunyit dan lengkuas merupakan komoditas yang menjadi prioritas untuk dikembangkan di Propinsi Jawa Tengah.

\section{Saran}

Berdasarkan hasil penelitian tersebut di atas sebaiknya pemerintah bersama-sama dengan pelaku industri tanaman obat meningkatkan kerjasama untuk meningkatkan peranan tanaman obat dalam perekonomian negara. Komoditas jahe sebaiknya ditingkatkan kualitasnya agar dapat memiliki daya saing dibandingkan komoditas dari daerah lain. 


\section{DAFTAR PUSTAKA}

Badan Litbang Pertanian. 2005. Prospek dan Arah Pengembangan Agribisnis Tanaman Obat. http://www.litbang. pertanian.go.id/special/komoditas/files/0 0-TANOBAT.pdf

Badan Litbang Pertanian. 2007. Prospek dan Arah Pengembangan Agribisnis Tanaman Obat Edisi Kedua. Badan Penelitian dan Pengembangan Pertanian Departemen Pertanian. Jakarta.

www.litbang.deptan.go.id/special/publikasi/doc _perkebunan/tanamanobat/tan-obatbagian a.pdf+prospek+dan+arah+ pengembangan+tanaman+obat diunduh tanggal 17 Oktober 2011

BPS, 2015. Jawa Tengah Dalam Angka. www.jateng.bps.go.id

Budiharsono,S. 2001. Teknik Analisis Pembangunan Wilayah Pesisir dan Lautan. Pradnya Paramita. Jakarta.

Chadhiq, U, Ismiyatun dan Nanang Yusroni. 2010. Analisis Penerapan Metode Basis dan Shift Share dalam Mengatasi Tingkat Disparitas Pendapatan Antar Wilayah Di Provinsi Jawa Tengah. Prosiding Seminar Nasional Unimus. Diunduh dari http://jurnal.unimus.ac.id/ index.php/psn12012010/article/view/99/ 80 pada tanggal 9 September 2016.

Kesuma, N.I.A dan I Made Suyana Utama. 2015. Analisis Sektor Unggulan dan Pergeseran Pangsa Sektor-Sektor Ekonomi Kabupaten Klungkung. EJurnal Ekonomi Pembangunan Universitas Udayana Vol. 4, No. 3, Maret 2015.

Kuncoro, M. 2004. Otonomi dan Pembangunan Daerah: Reformasi, Perencanaan, Strategi dan Peluang. Erlangga, Jakarta.
Lestari, ED. 2007. Analisis Daya Saing, Strategi dan Prospek Industri Jamu di Indonesia. Skripsi Fakultas Ekonomi dan Manajemen IPB. Bogor.

Lolowang, R., Antonius Luntungan dan Richard Tumilaar. 2014. Analisis Potensi Pertumbuhan Ekonomi Kabupaten Minahasa (Pendekatan Model Basis Eknomi dan Daa Saing Ekonomi. ejournal.unsrat.ac.id/index.php/jbie/artic le/download/5517/5044 diunduh tanggal 4 Oktober 2016.

Mangilaleng, E.J.,Debby Rotinsulu, dan Wensy Rompas. 2015. Analisis Sektor Unggulan Kabupaten Minahasa Selatan. Jurnal Berkala Ilmiah Efisiensi Volume 15 No. 04 Tahun 2015

Maximillian. 2007. Pasar Tumbuhan Obat; Agrofarmasi (Bagian 1). https://bisnisfarmasi.wordpress.com/200 7/02/19/pasar-biofarmaka-wow-bagian$1 /$

Oktavia, Z., Dwidjono Hadi Darwanto, Slamet Hartono. 2015. Sektor Pertanian Unggulan di Sumatera Selatan. Jurnal Agraris Vol. 1 No. 2 Juli 2015 diunduh dari journal.umy.ac.id/index.php/ag/ article/download/1116/1194 tanggal 9 September 2016.

Ratnasari, ED. 2014. Analisis Sektor-Sektor Pembentuk PDRB dan Penentuan Sektor Unggulan di Wilayah Kabupaten Kebumen. Jurnal Fokus Bisnis, Volume 13, No 01, bulan Juli 2014 diunduh dari http://journal.stieputrabangsa.ac.id/index. php/fokbis/article/view/8/5 tanggal 9 September 2016.

Suryana, 2000. Ekonomi Pembangunan Problematika dan Pendekatan, Salemba Empat, Jakarta. 